\title{
Mariusz Ruszel
}

\section{CHALLENGES AND OPPORTUNITIES OF THE COMMON EU ENERGY MARKET}

Europe needs a competitive economy that will be able to continuously compete with the dynamically developing markets of the United States of America, the People's Republic of China and India. Given the fact that the European economy faces numerous problems, this is no easy task. One way to improve its competitiveness is to lower energy $\operatorname{costs}^{1}$ and to improve the freedom of its deliveries to end users. The European Union (EU) has adopted a stringent climate policy which increases industrial production costs in Europe and contributes to workplaces being shifted to other parts of the world. EU politicians agreed to cut greenhouse gas emissions by $40 \%$ by $2030 .{ }^{2} \mathrm{EU}$ enterprises require compensating factors creating competitive advantages for them on the world market. One way to achieve these goals can be the creation of a common energy market which, will replace the previously monopolistic national markets of natural gas and electricity. With respect to the four main freedoms of trade in the EU, i.e. the free movement of goods, capital, services and people, it can be seen that the freedom of movement of goods is the basis of EU competences in the energy sector. This means that EU should influence the energy market in such a way that the exchange of natural gas and electricity can be free flowing and unrestricted. ${ }^{3}$ Therefore, the European Union needs to combine the particular markets in order to create

1 "European companies pay four times more for gas than their American competitors. Electric energy prices in the EU, already the highest among all OECD countries, are continuously rising. It is expected that until 2035 they will be 50\% higher than in the US and 300\% higher than in China. Energy prices significantly vary within the European Union itself. For example: electricity in Slovakia is twice as expensive as in Estonia.", Rynek energii, http://www.buzek.pl/node/7556 [access: 15.02.2014].

2 European Council (23 and 24 October 2014) Conclusions on 2030 Climate and Energy Policy Framework, European Council, SN 79/14, Brussels, 23.10.2014.

${ }^{3}$ R. Dohms, The development of a competitive internal energy market in the European Community, "Connecticut Journal of International Law" 1994, Vol. 9. 
interconnected energy networks as "energy highways" which could be used by anyone paying the proper fee. In this market structure there would be no so-called 'energy islands', i.e. no countries which would be isolated from the rest. The aim of this article is to analyse the challenges and opportunities related to the creation of a common EU energy market.

\section{The legal basis for the common energy market}

The legal basis for the common European Union energy market is Art. 194 of the Treaty on the Functioning of the European Union (TFEU). It states that "in the context of the establishment and functioning of the internal market and with regard for the need to preserve and improve the environment, Union policy on energy shall aim, in a spirit of solidarity between Member States, to: (a) ensure the functioning of the energy market; (b) ensure security of energy supply in the Union; (c) promote energy efficiency and energy saving and the development of new and renewable forms of energy; and (d) promote the interconnection of energy networks." ${ }^{4}$ At the same time it needs to be recalled that the Treaty of Lisbon treats the field of energy as an area divided between the Member States and EU institutions. Art. 4 of TFEU emphasizes that the competences will be divided in areas including the internal market, the natural environment, trans-European networks and energy. ${ }^{5}$

On 4 February 2011 the European Council adopted a political declaration concerning the goal of creation of a common energy market. It was emphasized that by 2014 a common market would be created, but it seems that this deadline is unrealistic. The European Council restated the principles concerning the common energy market in its conclusions of the 9 December 2011 and 22 May 2013. In this way the matter took a political course, around which legal and institutional regulations are to be created.

The regulatory environment of the energy market is constituted by the socalled energy packages, among which the III energy package plays an exceptionally important role. ${ }^{6}$ Its main purposes are to support the liberalisation of the market,

${ }^{4}$ Consolidated Version of the Treaty on the Functioning of the European Union, Official Journal of the European Union, C 83/47, 30.03.2010, p. 134-135.

${ }^{5}$ A. Lorkowski, M. Nowacki, Traktatowe uwarunkowania rozwoju polityki energetycznej UE, Nowa Europa, „Przegląd Natoliński” 2009, nr 1(8), p. 197-188.

${ }^{6}$ The III energy package includes: Directive 2009/72/EC of the European Parliament and of the Council of 13 July 2009 concerning common rules for the internal market in electricity and repealing Directive 2003/54/EC (the Electricity Directive); Directive 2009/73/EC of the European Parliament and of the Council of 13 July 2009 concerning common rules for the internal market in natural gas and repealing Directive 2003/55/EC (the Gas Directive); Regulation (EC) No 714/2009 of the European Parliament and of the Council of 13 July 2009 on conditions for ac- 
the improvement of energy security, an increase in transparency and supervision over the market, and the strengthening of consumer protection provisions. Moreover, the aim of these regulations is to guarantee access to energy infrastructure for third parties and also to separate the sales activities of an enterprise from its production and transmission activities. ${ }^{7}$ The intended result of the implementation of these regulations is the de-monopolization of the previous energy market structure in EU countries and their gradual integration into a common market. Thus it is necessary to modernise and extend the interconnections of natural gas and electricity. With this end in view the EU adopted Regulation (EU) No 994/2010 of the European Parliament and of the Council on 20 October 2010 concerning measures to safeguard security of gas supply and repealing Council Directive 2004/67/EC which persuades member states to create two-way gas interconnectors and also indicates tools which could be used in a crisis situation. Furthermore, Regulation (EU) No 347/2013 of the European Parliament and of the Council of 17 April 2013 on guidelines for trans-European energy infrastructure and repealing Decision No 1364/2006/EC and amending Regulations (EC) No 713/2009, (EC) No 714/2009 and (EC) No 715/2009 has been adopted, which indicates priority projects on the energy market. These two regulations will contribute to the creation of regional groups as a part of an integrated market. According to their provisions "by 31 December 2016, the European Network of Transmission System Operators for Electricity (ENTSO-E) and for Gas (ENTSO-G) shall jointly submit to the Commission and the Agency a consistent and interlinked electricity and gas market and network model including both electricity and gas transmission infrastructure as well as storage and LNG facilities, covering the energy infrastructure priority corridors and areas and drawn up in line with the principles laid down in Annex V."

cess to the network for cross-border exchanges in electricity and repealing Regulation (EC) No 1228/2003 (the Electricity Regulation); Regulation (EC) No 715/2009 of the European Parliament and of the Council of 13 July 2009 on conditions for access to the natural gas transmission networks and repealing Regulation (EC) No 1775/2005 (the Gas Regulation); and Regulation (EC) No 713/2009 of the European Parliament and of the Council of 13 July 2009 establishing an Agency for the Cooperation of Energy Regulators (the Agency Regulation).

${ }^{7}$ EU member states can choose one of three possibilities for dividing these activities. The first is the ownership unbundling, which consists in the integrated company selling its own networks and creating a separate entity which manages the networks. The second possibility is the legal separation of an independent operator, where the company can keep the ownership supervision over the transmission networks but member states could oblige this company to transfer the management of these networks to the independent operator. The third possibility consists in the integrity of sale and transmission of energy, but obliges both parts of the company to act independently. See: Trzeci pakiet energetyczny przyjęty!, http://www.europarl.europa.eu/sides/getDoc.do?pubRef=-//EP// TEXT+IM-PRESS+20080616FCS31737+0+DOC+XML+V0//PL [access: 10.01.2014].

${ }^{8}$ Regulation (EU) No 347/2013 of the European Parliament and of the Council of 17 April 2013 on guidelines for trans-European energy infrastructure and repealing Decision No 1364/2006/ EC and amending Regulations (EC) No 713/2009, (EC) No 714/2009 and (EC) No 715/2009, Official Journal of the European Union, L 115/39, 25.04.2013, p. 16. 
Apart from the regulatory environment, the institutional environment also plays an essential role. The main bodies of the EU take part in the decision making process and in the process of shaping the relevant legal acts. However, it has to be noted that new EU institutions supporting the process of creation of a common energy market also play an important role. Such institutions include the Agency for the Cooperation of Energy Regulators (ACER) ${ }^{9}$, ENTSO-E and ENTSO-G. Their activities are aimed at contributing to the regional integration of the natural gas and electricity markets and also to the approval of network codes. ${ }^{10}$

\section{Opportunities resulting from the common EU energy market}

First of all, the common EU energy market will contribute to an increase in the energy security of particular member states and will make it possible to react effectively in crisis situations. The integration and modernisation of gas networks and electrical power networks will facilitate two-way transmission of natural gas and electricity between countries. This means increasing the stability of functioning of the economy and decreasing the risks related to interruptions of natural gas supplies or failures of the electric power system. Simultaneously, an integrated energy market will be more energy-efficient.

Secondly, there will be more opportunities to freely choose one's natural gas and electricity provider. This will contribute to an increase in the competitiveness of energy companies supplying end users, and in this way should stimulate decreases in energy prices. If users choose the most favourable offer on the market, they will strengthen the position of the most competitive energy companies, which obtain energy from various sources. As a consequence, it can be expected that the integration of the market will influence changes in the structure of energy balance in particular countries, and the least advantageous methods for energy production will be forced out of the market. It will also have impact on the increase in energy efficiency on the pan-European scale, and as well will develop competitiveness. Currently, as far as electricity is concerned, the highest level of market concentration, which means the lowest competitiveness measured ac-

9 See: P. Newton, Does Acer hold all the aces?, http://www.utilityweek.co.uk/news/Does-Acer-hold-all-the-aces/775872\#.UwNpk860NqE [access: 5.01.2014].

10 "Network Codes are specific tools for implementation of a single energy market in the EU. They include common rules for functioning and managing energy systems and are aimed at eliminating technical barriers to further market integration. These codes are formulated by ENTSO-E and ENTSO-G and must be consistent with the non-binding Framework Guidelines set out by ACER." [in:] Framework Guidelines and Network Codes, http://www.ure.gov.pl/en/international-cooperat/third-energy-package/170,Framework-Guidelines-and-Network-Codes.html [access: 10.02.2014]. 
cording to the HHI index, ${ }^{11}$ occurs in countries such as Lithuania, Latvia, Estonia, France, Portugal, Greece and Italy. ${ }^{12}$ As far as natural gas is concerned, the highest market concentration occurs in countries such as Latvia, Ireland, Poland, France and Slovakia. ${ }^{13}$ In countries of the Visegrad Group (V4), the HHI index in 2001 on natural gas markets equalled 3905 in the Czech Republic, 5125 in Hungary, 6199 in Slovakia and 9029 in Poland. ${ }^{14}$ The integration of these four markets should lead to a decline in the HHI index in the region to the level of $2000,{ }^{15}$ and as a consequence, to the growth of competitiveness in this part of Europe.

Thirdly, the creation of a common energy market is an opportunity to modernise and extend the energy infrastructure in EU countries. It is particularly important to extend the transmission networks of natural gas and electricity, since in this way it is possible to integrate particular markets into regional groups. In October 2013 European Commission published a list of 248 priority projects of energy infrastructure for the years 2014-2020 which obtained the status of "Project of Common Interest" (PCI). These projects will be treated as a priority and will have the opportunity to obtain additional financial support. ${ }^{16}$ This list includes 12 projects from Poland. It should be noted that the implementation of PCI projects will not only influence the integration of energy markets, but also will contribute to increasing the energy security of Europe and also that of particular member states. ${ }^{17}$

Fourthly, the integrated energy market can contribute to higher transparency in trading in electricity and natural gas. Analysis of the Corruption Perception Index (CPI) shows that corruption is still a significant problem in the energy sector (data from 2013). ${ }^{18}$ European Union Member States which have a high corruption level include: Greece, Bulgaria, Italy, Romania, Slovakia, Croatia, Latvia, the Czech Re-

11 "HHI is the Hirschmann-Herfindahl Index, which is calculated by adding the squared market shares (in \% points) of relevant industry participants. Therefore, a HHI of 2000 could e.g. be achieved by five wholesalers with each having a market share of $20 \%$." [after:] J.-M. Glachant, A Vision for the EU Gas Target Model: the Meco-S Model, EUI Working Paper, Robert Schuman Centre for Advance Studies Florence School of Regulation, Firenze 2011, p. 13.

${ }^{12}$ O. Koch, Completing the Internal Energy Market, Vienna Forum, 8.03.2013, http://www. energy-community.org/pls/portal/docs/1926179.pdf, p. 8 [access: 9.02.2014].

${ }_{13}$ M. Culka, Measuring Energy Security in the European Natural Gas Market, Seminar Energiemodelle, Stuttgart 27.06.2012. http://www2.ier.uni-stuttgart.de/lehre/skripte/energiemodelle/ Culka_Erdgas_Versorgungssicherheit_SS2012.pdf, p. 28 [access: 8.02.2014].

${ }^{\overline{14}} \mathrm{~S}$. Ascari, The Gas Target Model for the Visegrad 4 Region. Conceptual analysis, Centre for Eastern Studies, Warsaw 2011, p. 32.

15 Ibidem.

${ }^{16} 12$ polskich projektów energetycznych na liście $P C I$, http://www.rynekinfrastruktury.pl/artykul/63/1/12-polskich-projektow-energetycznych-na-liscie-pci.html [access: 10.02.2014].

${ }_{17}$ M. Ruszel, Rola Unii Europejskiej w ksztaltowaniu bezpieczeństwa energetycznego Polski, [in:] Polska w Unii Europejskiej. Bilans dekady, ed. F. Tereszkiewicz, KPRP, Warszawa 2012, p. 272-293.

${ }^{18}$ M.-J., Fortelny, Corruption in the Energy Sector, Anchor Academic Publishing, Hamburg 2013. 
public, Lithuania, and Hungary. ${ }^{19}$ The energy market creates a whole range of tools which can be linked to the financial market and which can give rise, to a greater or lesser extent, to the misuse of funds. ${ }^{20}$ This justifies the validity of the adoption of Regulation (EU) No 1227/2011 of the European Parliament and of the Council of 25 October 2011 on wholesale energy market integrity and transparency. The aim of the regulations introduced is to increase confidence in the market, increase transparency, prohibit any manipulations on the market, and establish better pan-European supervision over sales on the common energy market.

\section{The threats and challenges of the common EU energy market}

The creation of a common energy market will create a series of challenges for member states and their energy companies. If they do not undertake proper actions, these challenges will become threats both for the companies and for the competitiveness of their national economies. This means that the common energy market currently in the process of creation should force energy companies to update their previous strategies, and contribute as well to the review of energy policies in European Union countries. Efficient functioning in free market conditions will be of utmost importance, as it will be necessary to compete for end users with other state and private enterprises from other countries. Therefore it is important for the public sector companies to make effective investment efforts now and to increase their energy efficiency and innovativeness in order to successfully compete in the international arena. It will be particularly vital for them to develop research and scientific cooperation with institutions of higher education and to create and strengthen their own research facilities.

A common energy market will not influence the energy balance structure of Member States directly, since the countries will be free to create their own "energy mix". However, it can indirectly contribute to changes in this structure, since the most competitive forms of energy production will have a competitive advantage on the free market. A lot will depend on whether the previous forms of support, the so-called feed-in-tariffs, ${ }^{21}$ will be retained or whether they will modified in the direction of the so-called feed-in-premiums. ${ }^{22}$ It has to be remem-

19 Corruption perceptions index 2012, Transparency International 2012.

${ }^{20}$ M.-J., Fortelny, Corruption in the..., p. 49-51.

21 "A feed-in tariff (FIT) is an energy supply policy focused on supporting the development of new renewable energy projects by offering long-term purchase agreements for the sale of RE electricity." [in:] T. Couture, K. Cory, C. Kreycik, E. Williams, A Policymaker's Guide to Feed-in Tariff Policy Design, Technical ReportNREL/TP-6A2-44849 July 2010 p. 22.

22 "Premium FIT: would pay a fixed premium on top of the variable wholesale electricity price." [in:] http://www.publications.parliament.uk/pa/cm201012/cmselect/cmenergy/742/74208. htm [access: 10.02.2014]. 
bered that currently many member states use various mechanisms for subsidising the energy sector and offer tax exemptions which contribute to the growth of competitiveness of their economies (e.g. exemption from excise duties for energy-consuming branches of industry). Consequently, EU countries will have to choose optimal ways of energy production and use those technologies which will provide for both cheap energy and the competitiveness of their energy industries.

The price of energy is not only a source of competitive advantage, but it also creates a series of economic challenges. Firstly, striving for the harmonisation of electricity prices on the common market can, over the long term, intensify the differences between particular regions, since the purchasing power of money in the EU countries is different. There is also the risk of an increase in the energy-poverty of the poorer parts of Europe, and of the acquisition of poorer national markets by strong players. Secondly, the strongest energy companies will be able to increase their competitive advantage with regard to the remaining energy companies and could finally take them over by implementing a policy of economic expansion. Thirdly, excessively low energy prices might not bring appropriate profits for the energy companies, which in turn will not want to invest in new systems of power generation. The lower the prices of energy, the higher the investment risk and the smaller is the incentive for new investments.

Taking into account that the EU wants to extend its energy infrastructure in an environmentally sustainable way, a simple calculation has to be made of those investors who will want to shift a part of environmental costs to end users. This means that, on the one hand, the price of energy has to be sufficiently low to ensure the competitiveness of European industry in the international economic rivalry, but on the other hand, not too low since the investment processes in the energy sector would be hampered.

Moreover, the competition internationally for consumers will create a considerable challenge for energy companies. It seems obvious that free market competition will contribute to the development of efficiency in companies' operations, but simultaneously it will create the threat of losing a part of their market. From the point of view of energy security of particular member states, this can lead to a situation whereby those energy companies which use the supply of energy resources or energy as a tool of political pressure will strengthen their position on the natural gas or electricity markets. At the same time, along with the increase in the strength of their position on the natural gas market of a given country, they will also contribute to an increase in the financial problems of those energy companies which have signed contracts for the supplies of natural gas for many years. If they are not able to sell the contracted quantities of the energy resource to the end users, their financial losses will accumulate and their shares will lose value on the stock exchange. As a consequence, a gradual consolidation of the assets of the energy sector may follow, which will endanger a given country since 
it may lose control of its energy infrastructure, which is obviously of strategic importance. In consideration of the above, it is crucial for the energy companies of a given country not only to compete for position on their own market, but also on the neighbouring markets.

It also should be noted that the creation of a common energy market requires the elimination of many barriers and the development of stable legal regulations which will guarantee free access to transmission networks for public energy. It is important not only for the EU institutions to prepare proper regulations in the form of directives or EU regulations, but also to develop a stability in the legal regulations in EU countries which will create proper investment conditions. It may be pointed out that currently there are too many market regulations which effectively restrain competition. It should also be emphasized that it may be necessary to deregulate the common energy market, which de facto has not been created yet. This confirms the necessity to develop efficient and effective tools shaping the energy market, which at the same time should be of a free market character.

It should also be mentioned that the integration of electrical power grids is a technical challenge, which consists in the attainment of proper compatibility of the grids and elimination of the risk of interruptions in the electrical energy flow. Currently, some parts of Europe witness the phenomenon of the so-called 'loop flows', which flow into electrical power grids of a neighbouring country and interfere with its energy security. Most certainly a factor which limits the optimal use of the electricity produced is the lack of storage facilities for electric energy. The industrial implementation of this type of technology will act as a catalyst for changes in the energy sector. A similar role can be played by an increase in the importance of construction materials which can be use for renewable sources of energy, which will contribute to increasing the energy self-sufficiency of households and industrial plants. Simultaneously, electric cars will become ever more popular and their batteries - now being the most expensive part of the vehicle - will gradually become cheaper. This forecasted "technological boom" will directly influence the common EU energy market and will necessitate 'updates' in the strategies of energy sector companies and the energy policies of particular countries.

\section{Conclusions}

The creation of a common EU energy market is a challenge which the governments of EU countries and EU institutions have to meet. The difficulties experienced so far in the scope of implementation of EU directives concerning the liberalisation of the energy market confirm that member states trying to reach the EU goals are simultaneously attempting to protect the interests of their own energy 
companies. Energy policy is a special area, where issues of energy solidarity overlap with the particularism of national interests. By retaining their prerogatives related to the shaping of the energy production infrastructure, member states will try to undertake actions which will boost their competitiveness on the common energy market. This means that energy companies will utilize those energy resources which, at a given point in time, will bring them the highest profits and ensure flexibility. This explains why some EU countries use hard coal more and more frequently, in spite of its high carbon dioxide emissions. Technological growth makes it possible to reduce the emission of greenhouse gases with regard to all the energy resources which have their place in the current production structure in Europe. It is important for Europe to skilfully take advantage of its natural resources, which will not only increase the energy self-sufficiency of the European Union, but also reduce its dependency on energy imports and contribute to the retention of jobs in Europe, in this way simultaneously stimulating the development of industrial policy. It is also essential to be able to fully exploit the opportunity to extract shale gas. The ongoing debate about the impact of the extraction of this unconventional gas on the natural environment should be viewed as an opportunity to adjust the existing technologies to the European conditions in order to facilitate the safe extraction of this resource. At the same time, it has to be emphasized that the EU climate policy requires revision and should become global. It is vital for the energy-climate policy to be the driving force of EU industrial policy. Otherwise Europe will be threatened with not only a gradual loss of workplaces, but also of its competitiveness in various branches of industry. As a result, growing unemployment could lead to new conflicts and social unrest in Europe. The provision of economic security for citizens is an important element influencing not only the improvement of the inhabitants' quality of life, but also increasing public safety.

The common energy market will not be created all at once. The political goals, already established and realized by means of legal and regulatory tools, show the path to reach the intended results. It is difficult to unambiguously determine which model of the energy market will be optimally compatible with the interests of all the entities functioning on this market. Nevertheless, it seems that the integration process will be implemented gradually and will concern first of all the creation of regional markets by forming an appropriate energy infrastructure. This process will force market players to look for advantages in the areas in which they are most effective. The threats and opportunities related to the creation of a common energy market should motivate Europe to act in solidarity. At the same time, the growing international competition can favourably affect the intensification of cooperation among EU countries which, because of changes on the international energy markets and geopolitical changes, will be forced to undertake closer economic cooperation and pursue energy solidarity. The growing competitiveness 
of the American and the Chinese energy industries can revive German-French ${ }^{23}$ cooperation, as well as the economic activity within the Weimar Triangle. It may be hoped that the growing economic competition in the world will act as a catalyst for the cooperation between EU member states, which need to increase their mutual understanding and trust, at the cost of national interests, in order to achieve the synergy which results from cooperation.

${ }^{23}$ P. Szalai, Interview with Damien Mathon, director, Syndicat des énergies renouvelables en France, http://www.europolitics.info/sectorial-policies/a-modest-binding-target-is-better-than-an-extremely-ambitious-one-art360042-14.html [access: 15.02.2014]. 